\title{
Autochthonous Starter Cultures Are Able to Reduce Biogenic Amines in a Traditional Portuguese Smoked Fermented Sausage
}

\author{
Igor Dias ${ }^{1,2,3, *(\mathbb{D})}$, Marta Laranjo ${ }^{1}(\mathbb{D})$, Maria Eduarda Potes ${ }^{1,4}(\mathbb{D}$, \\ Ana Cristina Agulheiro-Santos 1,5 (D), Sara Ricardo-Rodrigues 1(D), Ana Rita Fialho 1,t, \\ Joana Véstia ${ }^{1,+}$, Maria João Fraqueza ${ }^{6}\left(\mathbb{D}\right.$, Margarida Oliveira ${ }^{2,3,7}$ and Miguel Elias ${ }^{1,5}(\mathbb{D}$ \\ 1 MED-Mediterranean Institute for Agriculture, Environment and Development, IIFA-Instituto de \\ Investigação e Formação Avançada, Universidade de Évora, Pólo da Mitra, Ap. 94, 7006-554 Évora, Portugal; \\ mlaranjo@uevora.pt (M.L.); mep@uevora.pt (M.E.P.); acsantos@uevora.pt (A.C.A.-S.); \\ sirr@uevora.pt (S.R.-R.); rita.b.fialho@gmail.com (A.R.F.); joana.vestia@gmail.com (J.V.); \\ elias@uevora.pt (M.E.) \\ 2 CIEQV_Life Quality Research Centre, Avenida Dr. Mário Soares n 110, 2040-413 Rio Maior, Portugal; \\ margarida.oliveira@esa.ipsantarem.pt \\ 3 ESAS, UIIPS-Instituto Politécnico de Santarém, Quinta do Galinheiro, S. Pedro, \\ 1001-904 Santarém, Portugal \\ 4 Departamento de Medicina Veterinária, Escola de Ciências e Tecnologia, Universidade de Évora, Pólo da \\ Mitra, Ap. 94, 7006-554 Évora, Portugal \\ 5 Departamento de Fitotecnia, Escola de Ciências e Tecnologia, Universidade de Évora, Pólo da Mitra, Ap. 94, \\ 7006-554 Évora, Portugal \\ 6 CIISA-Centro de Investigação Interdisciplinar em Sanidade Animal, Faculdade de Medicina Veterinária, \\ Universidade de Lisboa, Avenida da Universidade Técnica, 1300-477 Lisboa, Portugal; \\ mjoaofraqueza@fmv.ulisboa.pt \\ 7 LEAF_L Linking Landscape, Environment, Agriculture and Food, Instituto Superior de Agronomia, \\ Universidade de Lisboa, Tapada da Ajuda, 1349-017 Lisboa, Portugal \\ * Correspondence: igor.dias@esa.ipsantarem.pt \\ † Former member of MED (formerly ICAAM-Instituto de Ciências Agrárias e Ambientais Mediterrânicas).
}

Received: 31 March 2020; Accepted: 3 May 2020; Published: 8 May 2020

Abstract: Traditional smoked fermented sausages are highly appreciated in Portugal and are mostly manufactured according to traditional procedures. The aim of the present work was to evaluate the effect of autochthonous starter cultures on the safety and quality of a smoked fermented sausage, Painho da Beira Baixa (PBB), preserving its sensory quality. Physicochemical parameters, namely $\mathrm{pH}$ and water activity $\left(\mathrm{a}_{\mathrm{W}}\right)$, microbiological parameters, biogenic amines, colour, texture profile and sensory attributes were assessed. Different starters were selected based on our previous work. Staphylococcus equorum S2M7, Staphylococcus xylosus CECT7057, Lactobacillus sakei CV3C2, Lactobacillus sakei CECT7056 and a yeast strain (2RB4) were co-inoculated in meat batters at defined concentrations. Starters had a significant effect on the reduction of $\mathrm{pH}$. Enterobacteria and Listeria monocytogenes were not detected in inoculated end-product sausages. Moreover, sausages inoculated with S. equorum S2M7/L. sakei CV3C2/yeast 2RB4 showed a significant reduction in the total content of biogenic amines. No significant differences between treatments were observed for colour and texture parameters, except for adhesiveness. The studied starters did not compromise the sensory characteristics of $P B B$. To our knowledge, this is the first comprehensive study on the quality and safety of this type of smoked fermented sausage from the central region of Portugal.

Keywords: smoked fermented sausages; Painho da Beira Baixa; starter cultures; biogenic amines; food safety; food quality 


\section{Introduction}

Meat processing extends the shelf-life of raw materials, thus valorising them and increasing their economic value. In Portugal, Beira Baixa is one of the most important regions for the production of dry-cured ham, but also of smoked fermented sausages, where products like Painho stand out for their unique organoleptic characteristics. These result from the manufacturing know-how of generations of sausage producers and small processing units, according to traditional practices specific to each geographical area.

Generally, dry-fermented meat sausages are stable products in which sanitary risks are reduced thanks to five main aspects: $\mathrm{pH}$ reduction (mainly due to the microbial fermentation of carbohydrates); a decrease in water activity throughout the curing process; the addition of nitrates and nitrites (with antimicrobial properties that prevent and/or eliminate pathogenic and deteriorating microorganisms); the eventual use of starters with antimicrobial activity; and smoking, when applied (for the bacteriostatic and bactericidal effects of smoke). However, the onset of emerging pathogens, which pose new safety concerns, and the pressure to reduce additives, due to health issues, have stressed the need to study the microbiota of processing environments. Furthermore, the need for a general improvement in process efficiency has also determined the introduction of innovative processes in meat industries. The introduction of starters, together with the rigorous control of all conditions throughout the curing process, are among the main tools adopted by meat industries to improve the sanitary, nutritional, and sensory qualities. These tools may result in further advantages to the technological process, such as a higher degree of compliance and the shelf-life extension of sausages [1-3]. In Portugal, the use of starters is not common in micro and small processing units. When used, the available starters are not adapted to our processes and meat products, with consequent changes in sensory attributes of regional smoked fermented meat sausages. Therefore, the selection of autochthonous strains, more adapted to these meat products, is necessary. In fact, starter cultures are pure (individual) or mixed microbiological cultures of known microorganisms, inoculated at defined concentrations [4], that may promote and conduct the fermentation of sausages [5]. They significantly contribute to the quality and safety of meat products, mainly through their bioprotective (inhibition of foodborne pathogens growth) and fermentative/probiotic (production of secondary metabolites) actions [6-8]. Nevertheless, some authors reported that the use of starter cultures in sausages could slightly increase the content of biogenic amines [9]. However, recent studies have shown that autochthonous starter cultures may control the accumulation of biogenic amines in fermented meat products, while retaining their sensory characteristics $[10,11]$.

Nowadays, the microorganisms mainly used as starters in the meat processing industry belong to four groups: (1) lactic acid bacteria (LAB) from the genus Lactobacillus, namely L. sakei, L. plantarum and L. curvatus; (2) Gram-positive catalase positive bacteria, such as coagulase-negative staphylococci (CNS), namely S. xylosus and S. equorum, and Micrococcaceae, namely Kocuria spp. [12-14]; (3) yeasts, such as Debaromyces spp. [15,16]; and (4) moulds of the genus Penicillium [17]. The first two groups are used for the inoculation of meat batters, the third group can be inoculated both in meat batters and on the surface of sausages, and the fourth group is used for the superficial inoculation of sausages $[13,14,18,19]$.

The aim of the present study was to evaluate the effects of different autochthonous starter cultures on the safety and quality of Painho da Beira Baixa, a traditional Portuguese smoked fermented sausage produced on a small scale in a local small manufacturing unit.

\section{Materials and Methods}

\subsection{Smoked Fermented Sausage Manufacturing and Sampling}

Painho da Beira Baixa, a traditional smoked fermented sausage, was manufactured in a local factory using commercial white pig meat.

Pork meat trimmings ( $70 \%$ lean meat $/ 30 \%$ fat) were mechanically cut into cubes of 35 to $45 \mathrm{~mm}$ and mixed with white wine $(5.0 \% v / v)$, salt $(2.5 \%$ w/w), red pepper (Capsicum annuum L.) paste $(2.5 \%$ 
$w / w)$, water $(2.0 \% v / v)$, garlic (Allium sativum L.) paste $(0.8 \% w / w)$, powder laurel (Laurus nobilis L.) $(0.005 \% w / w)$, polyphosphates $(0.06 \% w / w)$, nitrates $(0.007 \% w / w)$, nitrites $(0.003 \% w / w)$ and ascorbic acid $(0.04 \% w / w)$.

Three independent batches of each treatment were prepared over time with a unit weight of approximately $150 \mathrm{~kg}$ (meat batter). Food grade dextrose (0.25\%) was added to all treatments.

Starters and used concentrations were selected based on previous work [20,21] and were co-inoculated in the meat batters. In these earlier studies, different concentrations were tested in pure and mixed cultures. The best combinations of mixed culture/concentration were selected for further studies. Bacteria were inoculated at a concentration of $10^{8} \mathrm{cfu} / \mathrm{g}$ of meat batter, whereas the yeast was co-inoculated at a concentration of $10^{6} \mathrm{cfu} / \mathrm{g}$ of meat batter.

Five treatments were considered: 1-control (no starter cultures added); 2-Staphylococcus equorum S2M7/Lactobacillus sakei CV3C2; 3-S. equorum S2M7/L. sakei CV3C2/yeast 2RB4; 4-Staphylococcus xylosus CECT7057/Lactobacillus sakei CECT7056 and 5-S. xylosus CECT7057/L. sakei CECT7056/yeast 2RB4).

The strains S. equorum S2M7 and L. sakei CV3C2 were previously isolated and studied [22]. S. xylosus CECT7057 and L. sakei CECT7056 were isolated by Elias [21] and successfully used as starters in Paio from Alentejo. These two strains were latter subjected to a patent both in Portugal and in Spain.

Each meat batter was stored under controlled conditions at $5{ }^{\circ} \mathrm{C}$ and $90 \%$ relative humidity for $72 \mathrm{~h}$ for ripening purposes. Afterwards, the batter was stuffed into pork natural casings of $50-55 \mathrm{~mm}$ (pig's large intestine). Salted natural casings were desalted as follows: casings were washed with running water, acetic acid (3.0\% $v / v)$ and commercial disinfectant (Desitripa, Formulab, Maia, Portugal) for $1 \mathrm{~h}$. After draining, washed casings may be stored at $5{ }^{\circ} \mathrm{C}$ for a maximum of $24 \mathrm{~h}$. Freshly stuffed sausages (weighting around 400-450 g/each) were left to ferment for $48 \mathrm{~h}$ at room temperature (between 15.1 and $22.3^{\circ} \mathrm{C}$ ), before they were smoked in a traditional smokehouse with natural smoke from Quercus ilex wood combustion. Sausages were continuously smoked (about 10 days) until they reached $38 \%-40 \%$ weight losses. Each sausage (end-product) weighted around $240-270 \mathrm{~g}$. Temperature and relative humidity in the traditional smokehouse were monitored and registered with a data logger (Ebro EBI-20 THP, Ingolstadt, Germany), showing variations between 10.5 and $48.4^{\circ} \mathrm{C}$, and $31.7 \%$ and $84.8 \%$, respectively.

Two separate sausages per treatment and per batch were collected throughout the curing process at four different steps: meat batter (immediately before stuffing), fermented sausage ( $48 \mathrm{~h}$ after stuffing and maintained at room temperature in the smokehouse antechamber), half-cured sausage (7 days after stuffing) and end-product ( $38 \%-40 \%$ weight losses).

$\mathrm{PH}, \mathrm{a}_{\mathrm{W}}$, microbiological parameters and contents of biogenic amines were determined at all curing steps. Evaluations of colour, texture profile analysis and sensory analysis were only performed in end-products.

\subsection{Physicochemical Analyses}

\subsubsection{Determination of $\mathrm{pH}$ and $\mathrm{a}_{\mathrm{w}}$}

Casings were removed, the sausages were minced, and $\mathrm{pH}$ was measured with a Crison 507 (Crison, Barcelona, Spain) pH-meter following the procedures described in ISO 2917 [23]. Water activity (aw) was determined at $25{ }^{\circ} \mathrm{C}$ with a hygrometer (Hygroskop Rotronic DT, Zurich, Switzerland) equipped with a WA-40 probe. Five replicates per sample were used.

\subsubsection{Colour}

Colour was measured with a Konica Minolta CR-400 colorimeter (Konica Minolta Inc., Tokyo, Japan) on cross-sections immediately after cutting the sausages (to prevent colour degradation). Five replicates per sample were tested at room temperature $\left(20 \pm 1^{\circ} \mathrm{C}\right)$. The CIELab chromatic coordinates lightness $\left(L^{*}\right)$, redness/greenness $\left(a^{*}\right)$ and yellowness/blueness $\left(b^{*}\right)$ were measured and 
chroma $\left(\mathrm{C}^{*}=\left(\left(\mathrm{a}^{*}\right)^{2}+\left(\mathrm{b}^{*}\right)^{2}\right)^{0.5}\right)$ and hue angle $\left(\mathrm{H}^{\circ}=\arctan \left(\mathrm{b}^{*} / \mathrm{a}^{*}\right)\right)$ were calculated. All measurements were performed using the standard illuminant D65.

\subsubsection{Texture Profile Analysis (TPA)}

Texture profile analysis (TPA) was performed at room temperature $\left(20 \pm 1^{\circ} \mathrm{C}\right)$ using a Stable Micro System TA-Hdi (Stable Micro Systems, Godalming, England) following the procedures described before [24,25]. Cross-section samples ( $1 \mathrm{~cm}$ thick) were compressed twice in two consecutive cycles of $50 \%$ compression with $5 \mathrm{~s}$ breaks between cycles. A cylindrical flat-ended probe (with an area of $1 \mathrm{~cm}^{2}$ ) was actioned at a constant speed of $1 \mathrm{~mm} \mathrm{~s}^{-1}$. Five replicates per sample were used. Hardness $(\mathrm{N})$, adhesiveness $\left(\mathrm{N} \cdot \mathrm{s}^{-1}\right)$, springiness, cohesiveness, resilience and chewiness $(\mathrm{N})$ were calculated from the obtained force-time curves.

\subsection{Microbiological Analyses}

Microbiological analyses were performed following international standards and established procedures: mesophiles following ISO 4833-1 [26]; psychrotrophic microorganisms, ISO 17410 [27]; lactic acid bacteria (LAB) according to ISO 15214 [28], under anaerobiosis; staphylococci as described by Laranjo et al. [29]; yeasts and moulds, ISO 21527-2 [30]; enterobacteria following ISO 21528-2 [31]; and Listeria monocytogenes according to ISO 11290-2 [32]. For the detection of Salmonella spp., a VIDAS enzyme-linked fluorescent immunoassay (bioMérieux, Marcy-l'Étoile, France) was used. All positive results were confirmed according to ISO 6579-1 [33]. All microbiological analyses were performed in triplicate, and the results were expressed as log colony-forming units ( $\mathrm{cfu} / \mathrm{g}$, except for L. monocytogenes counts, which were reported as cfu/g.

\subsection{Biogenic Amines Profile}

Biogenic amine quantification was performed according to the experimental protocol described by Roseiro et al. [34]. Samples were homogenised using an IKA brand homogeniser, Ultra Turrax digital T25 model and 18G ST probe (Staufen im Breisgau, Germany) and extracted with $0.4 \mathrm{M}$ perchloric acid (Panreac, Barcelona, Spain). 1,7-diaminoheptane (Merck, New Jersey, USA) was added as an internal standard. Sample extracts were derivatised with dansyl chloride $(5 \mathrm{mg} / \mathrm{mL}$ acetone, $v / v$ ). Individual biogenic amines were separated and quantified in a Thermo Scientific Dionex High Performance Liquid Chromatography (HPLC) system, model Ultimate 3000 (Massachusetts, USA), equipped with a quaternary pump (HPLC Ultimate 3000 pump), automatic extractor (Ultimate 3000 Autosampler) and Array diode detector (DAD) (Ultimate 3000 RS Diode Array detector). The wavelength was adjusted to $254 \mathrm{~nm}$, and an RP-18 reverse phase column $(5 \mu \mathrm{m}$ of $4.0 \times 125 \mathrm{~mm}$ and $100 \mathrm{~A}^{\circ}$ ) was used (Merck, NJ, USA). An elution program was carried out with a mixture of $0.1 \mathrm{M}$ ammonium acetate (solvent A) and acetonitrile (solvent B). Quantification was done by external calibration, through the integration of areas obtained from a mixture of individual standards of known concentration.

All samples were extracted in duplicate, and each replicate was twofold derivatised. All replicas were injected twice. The following biogenic amines were quantified: tryptamine, $\beta$-phenylethylamine, putrescine, cadaverine, histamine, tyramine, spermidine and spermine. The content of each biogenic amine was expressed in $\mathrm{mg} / \mathrm{kg}$ of fresh weight.

The content of vasoactive amines was calculated based on the sum of tryptamine, $\beta$-phenylethylamine, histamine and tyramine [35]. The total content of biogenic amines was calculated using the sum of all eight individual amines.

Chromatographic data were processed using the Chromeleon software version 6.8 (Thermo Scientific Dionex, MA, USA). 


\subsection{Sensory Analysis}

Ten panellists were trained and selected following ISO 8586-1 [36]. Sensory evaluation took place in a specially prepared room in accordance with ISO 8589-1 [37]. Thirty minutes prior to each session, the sausages were sliced ( $3 \mathrm{~mm}$ thick) and the slices were randomly distributed in white dishes. Each dish was identified with a random three-digit number. Crackers and mineral water were provided, for the panellists to rinse their mouths between evaluations. The panellists were asked to evaluate products according to several attributes, using a quantitative descriptive analysis with a scale ranging from 0 to 100 corresponding to "no perception" or "maximum perception". The evaluated attributes were colour intensity, off-colours, marbled, aroma intensity, off-aromas, hardness, fibrousness, succulence, flavour intensity, off-flavours, salt perception and overall appreciation. For hardness and salt perception, an optimum value of 50 was considered. Each panellist evaluated six samples per session.

\subsection{Statistical Analysis}

Data were analysed using the StatisticaTM v.8.0 software from Statsoft (StatSoftInc, 1984-2007, Tulsa, OK, USA). The elimination of outlier data was carried out according to the Grubbs test $(\alpha=0.05)$.

Multi-factor analyses of variance or one-way ANOVAs were performed, and significantly different means were compared with the Tukey's Honest Significant Difference (Tukey's HSD) test $(p<0.05)$.

\section{Results and Discussion}

\section{1. $p H$ and $a_{W}$}

Table 1 summarizes the results for $\mathrm{pH}$ and $\mathrm{a}_{\mathrm{W}}$ for the smoked fermented sausages subjected to different inoculation treatments. The values for both parameters gradually decreased throughout the curing process.

Table 1. Effect of starter cultures on the $\mathrm{pH}$ and $\mathrm{a}_{\mathrm{W}}$ of smoked fermented sausages.

\begin{tabular}{|c|c|c|c|c|c|}
\hline \multirow{2}{*}{ Parameters } & \multirow{2}{*}{ Treatment } & \multicolumn{4}{|c|}{ Curing Steps } \\
\hline & & Meat Batter & Fermented Sausage & Half-Cured Sausage & End-Product \\
\hline \multirow{5}{*}{$\mathrm{pH}$} & 1 & $5.78^{\mathrm{A}, \mathrm{a}} \pm 0.10$ & $5.59^{\mathrm{B}, \mathrm{a}} \pm 0.03$ & $5.08^{\mathrm{C}, \mathrm{a}} \pm 0.07$ & $5.12^{\mathrm{C}, \mathrm{a}} \pm 0.18$ \\
\hline & 2 & $5.47^{\mathrm{A}, \mathrm{b}} \pm 0.22$ & $5.33^{\mathrm{B}, \mathrm{bc}} \pm 0.11$ & $4.97^{\mathrm{C}, \mathrm{b}} \pm 0.04$ & $4.92^{\mathrm{C}, \mathrm{b}} \pm 0.08$ \\
\hline & 3 & $5.43^{\mathrm{A}, \mathrm{b}} \pm 0.20$ & $5.30^{\mathrm{B}, \mathrm{c}} \pm 0.09$ & $4.95^{\mathrm{C}, \mathrm{b}} \pm 0.04$ & $4.92^{\mathrm{C}, \mathrm{b}} \pm 0.11$ \\
\hline & 4 & $5.47^{\mathrm{A}, \mathrm{b}} \pm 0.23$ & $5.30^{\mathrm{B}, \mathrm{bc}} \pm 0.06$ & $4.97^{\mathrm{C}, \mathrm{b}} \pm 0.03$ & $4.96^{\mathrm{C}, \mathrm{b}} \pm 0.12$ \\
\hline & 5 & $5.48^{\mathrm{A}, \mathrm{b}} \pm 0.21$ & $5.35^{\mathrm{B}, \mathrm{b}} \pm 0.07$ & $4.98^{\mathrm{C}, \mathrm{b}} \pm 0.05$ & $4.95^{\mathrm{C}, \mathrm{b}} \pm 0.08$ \\
\hline \multirow{5}{*}{$a_{W}$} & 1 & $0.975^{\mathrm{A}, \mathrm{a}} \pm 0.009$ & $0.950^{\mathrm{B}, \mathrm{b}} \pm 0.004$ & $0.915^{\mathrm{C}, \mathrm{ab}} \pm 0.009$ & $0.876^{\mathrm{D}} \pm 0.006$ \\
\hline & 2 & $0.974^{\mathrm{A}, \mathrm{ab}} \pm 0.012$ & $0.963^{\mathrm{B}, \mathrm{a}} \pm 0.012$ & $0.914^{\mathrm{C}, \mathrm{ab}} \pm 0.007$ & $0.880^{\mathrm{D}} \pm 0.008$ \\
\hline & 3 & $0.968^{\mathrm{A}, \mathrm{bc}} \pm 0.005$ & $0.965^{\mathrm{A}, \mathrm{a}} \pm 0.017$ & $0.915^{\mathrm{B}, \mathrm{ab}} \pm 0.013$ & $0.879^{C} \pm 0.003$ \\
\hline & 4 & $0.964^{\mathrm{A}, \mathrm{bc}} \pm 0.008$ & $0.962^{\mathrm{A}, \mathrm{a}} \pm 0.011$ & $0.919^{\mathrm{B}, \mathrm{a}} \pm 0.005$ & $0.881^{C} \pm 0.015$ \\
\hline & 5 & $0.961^{\mathrm{A}, \mathrm{d}} \pm 0.006$ & $0.953^{\mathrm{B}, \mathrm{b}} \pm 0.009$ & $0.912^{\mathrm{C}, \mathrm{b}} \pm 0.014$ & $0.877^{\mathrm{D}} \pm 0.014$ \\
\hline
\end{tabular}

Data are expressed as means \pm SD. 1-control; 2-S. equorum S2M7/L. sakei CV3C2; 3-S. equorum S2M7/L. sakei CV3C2/yeast 2RB4; 4-S. xylosus CECT7057/L. sakei CECT7056; 5-S. xylosus CECT7057/L. sakei CECT7056/yeast 2RB4. For the same treatment and in the same row, distinct capital letters $\left({ }^{A-D}\right)$ represent significantly different means $(p<0.05)$. For each curing step and in the same column, distinct lowercase letters $\left.{ }^{\left({ }^{a}-d\right.}\right)$ represent significantly different means $(p<0.05)$.

For $\mathrm{pH}$, the control meat batter had a significantly higher mean value $(5.78 \pm 0.10)$ than all four inoculated meat batters, which showed no differences among them. The exact same is true for the fermented sausage, which means that keeping the sausages at temperatures close to $20^{\circ} \mathrm{C}$ after stuffing allowed the microbiota to continue to multiply noticeably. This contributed to acid production, with the concomitant significant reduction of the mean $\mathrm{pH}$ values compared to the control. Franciosa et al. [1] and McLeod et al. [38] stated that the good adaptation of LAB to the conditions existing in the meat batters can contribute to their rapid multiplication. The fast proliferation of LAB is relevant in sausage 
manufacturing, as it leads to the metabolization of sugar with the consequent formation of organic acids, mainly lactic acid, which promotes a $\mathrm{pH}$ decrease [6,39]. Lowering the $\mathrm{pH}$ is essential as it contributes to the safety, development of a characteristic taste, colour, and aroma, as well as to the microbiological stability of the product. Regarding end-products, control sausages still had a significantly higher mean $\mathrm{pH}(5.12 \pm 0.18)$, and there were no differences between inoculated sausages. It should be noted that inoculated sausages had mean values below 5.0, meaning that the pH dropped more slowly in the control group. These conclusions agree with those reported by others $[8,18,40]$. Our values were generally lower than those of other authors, in the meat batter as well as in end-products $[12,18,19,40]$. The addition of white wine in the formulation may have contributed to our lower $\mathrm{pH}$ values.

Concerning $\mathrm{a}_{\mathrm{W}}$, there were no considerable differences between inoculated and control sausages. The $\mathrm{a}_{\mathrm{W}}$ values obtained for end-products, although higher than those obtained by other authors $[12,18,19,40]$, are within the acceptable range that does not compromise microbial stability or the overall quality of the sausages.

Our results are similar to those reported in the literature. Cruxen et al. [12] described a typical fermented meat sausage with a water activity $\left(\mathrm{a}_{\mathrm{W}}\right)$ of 0.92 and $\mathrm{pH}$ values between 4.8 and 5.5 . Leistner and Rödel [41] reported that sausages with a pH below 5.2 and aw below 0.95 , or pH below 5.0 or $\mathrm{a}_{\mathrm{W}}$ below 0.91 , are stable food products that do not need refrigeration temperatures for preservation purposes. Hierro et al. [42] indicated values below 0.90 for $\mathrm{a}_{\mathrm{W}}$ and 5.5 for $\mathrm{pH}$ as a good rule of thumb to maintain a high level of food hygiene in sausages.

\subsection{Characterisation of the Microbiota throughout the Curing Process}

The results for all microbiological analyses are summarised in Table 2. No Salmonella spp. was detected for any of the tested samples. This agrees with other authors stating that fermentation and curing are effective in the control of pathogens [43,44]. Hajmeer et al. [45] reported that smoking and the high temperatures associated with the smoking process had an antimicrobial effect on pathogenic microorganisms, such as C. jejuni, E. coli O157:H7, L. monocytogenes, S. enterica and Y. enterocolitica.

Significant differences were observed between control and inoculated meat batters for mesophiles, psychrotrophic microorganisms, LAB, staphylococci and yeasts, which could be related to the addition of starter cultures, as previously reported [8,40]. In fact, much higher LAB counts were observed in the inoculated meat batters. Initial LAB counts for inoculated meat batters were 3 to $4 \log$ units higher than the control, reflecting the inoculation and, simultaneously, that the strains were able to rapidly multiply and adapt to the meat batter environment. Afterwards, LAB counts increased and remained high, for all treatments, up to the end-product. These steady LAB numbers throughout the curing are probably due to the decrease in fermentable carbohydrates [46] and water activity [40]. In line with the results obtained by other authors $[40,47,48]$, they remained the dominant microbial group in end-products (7.32-8.61 log cfu/g). Our data reveal that the inoculated strains are well adapted to the meat batter. In fact, L. sakei is referred to as the prevalent species in fermented meat sausages due to its ability to adapt regarding processing conditions [49,50].

The enumeration of mesophilic microorganisms, the origin and behaviour of which are quite heterogeneous in the microbiota of sausages, is not considered a good indicator of food hygiene for this type of meat product, reflecting the generally high LAB counts observed in this study.

The counts of psychrotrophic microorganisms were slightly lower than those of mesophiles, which is in agreement with the results obtained by others [51-53] that reported psychrotrophic microorganisms to be usually lower than mesophiles in this type of sausage.

Staphylococci counts generally decreased from the meat batter and fermented sausage steps to the subsequent curing steps. Control meat batters showed a significantly lower mean value $(3.30 \pm 0.42 \log \mathrm{cfu} / \mathrm{g})$ than inoculated meat batters. Regarding fermented sausages, non-inoculated sausages had significantly lower staphylococci numbers when compared to the sausages inoculated with S. xylosus CECT7057/L. sakei CECT7056/yeast 2RB4. Considering half-cured sausages and end-products, there were no significant differences between treatments. The mean 
staphylococci count in end-products was between 3.51 and $4.19 \log \mathrm{cfu} / \mathrm{g}$. The decrease in staphylococci numbers was perhaps due to the poor competitiveness of staphylococci against LAB, which is associated with a $\mathrm{pH}$ decrease (reaching values below 5.0 in the present study), as already reported by other authors $[8,54,55]$. Furthermore, the two starter staphylococcal species have shown different performances. The $S$. xylosus strain is more persistent in meat batters and fermented sausages and performs better than the $S$. equorum strain in competition with the autochthonous microbiota. However, it seems to be strongly affected by smoke, since the staphylococci counts in the treatments with S. xylosus decreased by approximately 3 logs after the smoking step.

Table 2. Effect of starter cultures on the microbiological parameters of smoked fermented sausages.

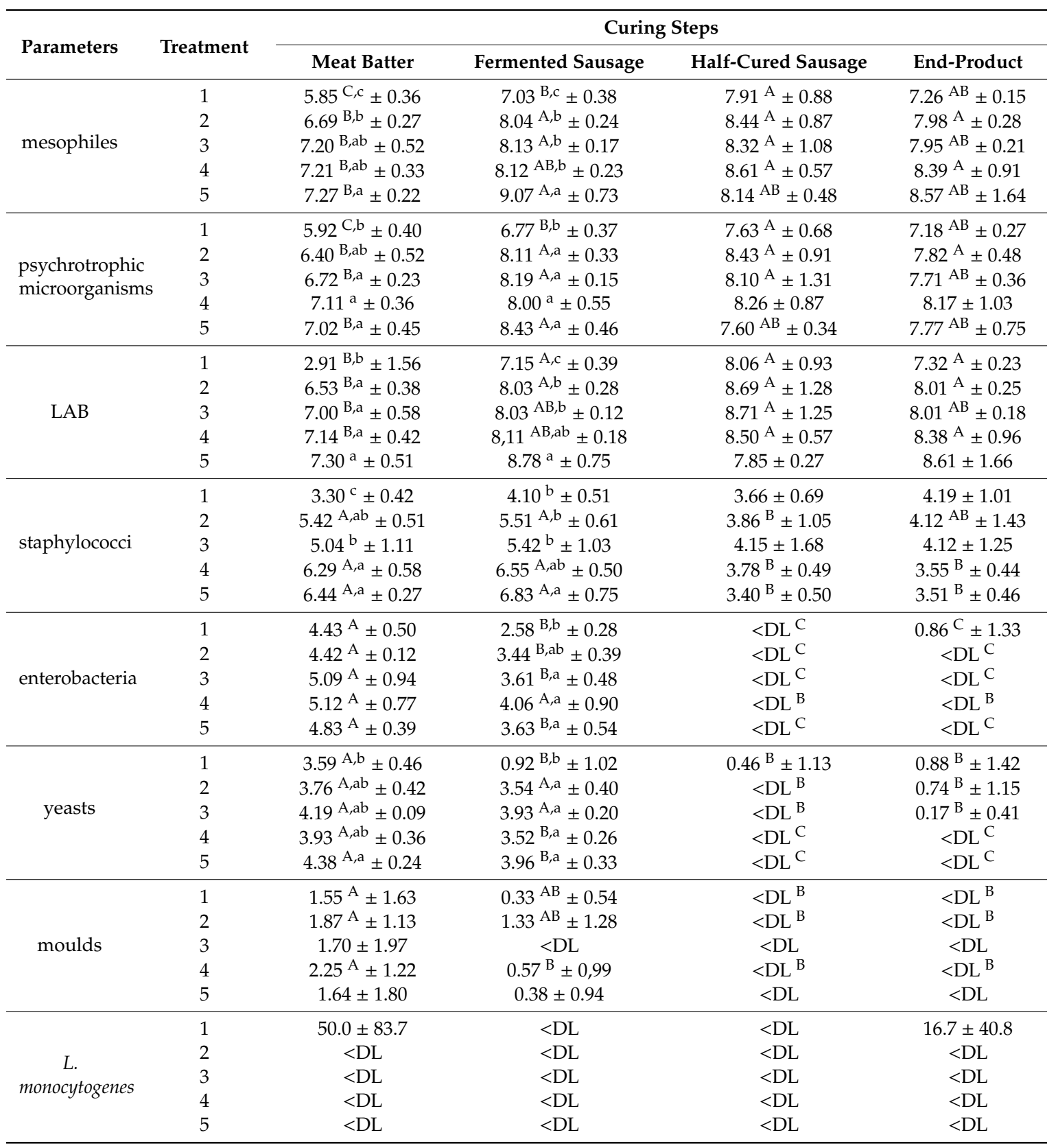

Data are expressed as means \pm SD. $<$ DL: below the detection limit of the corresponding analytical method (10 cfu/g). Results are expressed in log cfu/g. Results for L. monocytogenes are reported as cfu/g. 1 -control; 2 -S. equorum S2M7/L. sakei CV3C2; 3-S. equorum S2M7/L. sakei CV3C2/yeast 2RB4; 4-S. xylosus CECT7057/L. sakei CECT7056; 5-S. xylosus CECT7057/L. sakei CECT7056/yeast 2RB4. For the same treatment and in the same row, distinct capital letters $\left({ }^{A-C}\right)$ represent significantly different means $(p<0.05)$. For each curing step and in the same column, distinct lowercase letters ${ }^{\mathrm{a}-\mathrm{c}}$ ) represent significantly different means $(p<0.05)$. 
Regarding enterobacteria, no significant differences were observed in the meat batters. However, in the fermented sausages, significant differences were noticed, with inoculated sausages showing more enterobacteria. Concerning half-cured sausages, enterobacteria numbers were below the detection limit of the method for all treatments. Nevertheless, control end-products still showed a low number of enterobacteria $(0.86 \pm 1.33 \log \mathrm{cfu} / \mathrm{g})$, which may evidence the role of starters in eliminating/reducing enterobacteria. Other authors, such as Cadavez et al. [56], Lorenzo et al. [40] and Garcia Fontan et al. [57], obtained higher values in end-products (approximately 1 to $3 \log \mathrm{cfu} / \mathrm{g}$, depending on the treatment). It should be noted that Cadavez et al. [56] and Garcia Fontan et al. [57] also used traditional smoking to dehydrate the sausages, while Lorenzo et al. [40] did not.

Concerning yeast numbers, significant differences in the meat batter step were only observed between control and the meat batter inoculated with S. xylosus CECT7057/L. sakei CECT7056/yeast 2RB4, with the latter having higher counts. Regarding fermented sausages, control sausages had a significantly lower mean value than inoculated sausages. Both in half-cured sausages and end-products, no significant differences were observed between treatments, and the counts were generally low, with the highest numbers being for control sausages. Our yeast counts are much lower than those determined by Andrade et al. [58], who produced Spanish salchichón inoculated with several strains of D. hansenii at a concentration of approximately $10^{6}$ cells/g of meat batter; added dextrin, dextrose and lactose (in a commercial mix with unknown individual concentrations); and did not smoke the sausages. Those authors obtained relatively constant yeast numbers (3.0-6.0 log cfu/g) throughout the production process. It should be noted that the lowest counts were always obtained for control sausages. Our low yeast numbers may be due to smoking but also due to the fact that yeasts cannot compete with the microbiota present in the sausage environment, including the inoculated starter bacteria. In fact, Encinas et al. [59] reported lower values for smoked sausages compared to non-smoked ones. Leistner [60] also reported smoking to affect yeast counts but that factors such as time and temperature play a major role.

Moulds showed relatively low numbers throughout the curing process, with no differences between treatments at all curing steps, and with no moulds at all being detected in end-products. It is common that no moulds appear in end-product sausages. Casquete et al. [53]—in Spanish chorizo and salchichón, inoculated with Pediococcus acidilactici and Staphylococcus vitulus at concentrations of approximately $5 \times 10^{7}$ cells/g of meat batter-started the curing process with mean values between 1.48 and $2.34 \log \mathrm{cfu} / \mathrm{g}$ and ended up with mean values close to $2 \log \mathrm{cfu} / \mathrm{g}$ in the end-products, with no significant differences between treatments. Alves et al. [61] obtained values close to $0.70 \mathrm{log} \mathrm{cfu} / \mathrm{g}$ in non-inoculated Alentejano pig sausages and close to $1.5 \log \mathrm{cfu} / \mathrm{g}$ for non-inoculated Iberian $\mathrm{X}$ Duroc pig sausages, for the end-products. Our results were even lower than those in the end-products, which may be an indicator of microbial stability, since high mould concentrations in end-products may lead to sensory impairments [17,62].

For L. monocytogenes, all results were below the detection limit of the method for all treatments, in both fermented and half-cured sausages. Moreover, L. monocytogenes was only detected in the non-inoculated meat batter $(5.00 \pm 8.37 \mathrm{cfu} / \mathrm{g})$ and end-products $(1.66 \pm 4.08 \mathrm{cfu} / \mathrm{g})$, which may indicate an antimicrobial action of the used starters against L. monocytogenes. However, it should be noted that all counts were lower than those specified in the current legislation: $100 \mathrm{cfu} / \mathrm{g}$ for ready-to-eat foods likely to allow the growth of L. monocytogenes, except those intended for infants and for specific medicinal purposes, according to Commission Regulation (EC) No 1441/2007 amending Regulation (EC) No 2073/2005 on microbiological criteria for foodstuffs [63]. Thus, starters seem to have had an important effect on the inhibition of this foodborne pathogen, as also reported by Cenci-Goga et al. [64].

\subsection{Biogenic Amine Profile}

Table 3 shows the content of biogenic amines for each treatment throughout the curing process. The main identified individual biogenic amines, in decreasing order of concentration, were tryptamine, 
spermine, putrescine and cadaverine. Histamine and $\beta$-phenylethylamine were only present at very low concentrations.

Table 3. Effect of starter cultures on the content in biogenic amines ( $\mathrm{mg} / \mathrm{kg}$ fresh weight) of smoked fermented sausages.

\begin{tabular}{|c|c|c|c|c|c|}
\hline \multirow{2}{*}{ Parameters } & \multirow{2}{*}{ Treatment } & \multicolumn{4}{|c|}{ Curing Steps } \\
\hline & & Meat Batter & Fermented Sausage & Half-Cured Sausage & End-Product \\
\hline \multirow{5}{*}{ tryptamine } & 1 & $138.70^{\mathrm{ab}} \pm 108.00$ & $131.51 \pm 60.31$ & $74.17 \pm 44.80$ & $132.72^{\mathrm{a}} \pm 60.44$ \\
\hline & 2 & $112.17^{\mathrm{b}} \pm 68.07$ & $119.88 \pm 53.81$ & $72.26 \pm 41.23$ & $104.34^{\mathrm{ab}} \pm 21.60$ \\
\hline & 3 & $158.05^{\mathrm{A}, \mathrm{ab}} \pm 38.34$ & $133.05^{\mathrm{AB}} \pm 64.67$ & $93.09^{\mathrm{BC}} \pm 31.79$ & $86.03^{\mathrm{C}, \mathrm{b}} \pm 8.84$ \\
\hline & 4 & $208.21^{\mathrm{A}, \mathrm{a}} \pm 86.79$ & $107.23^{B} \pm 38.17$ & $85.21^{\mathrm{B}} \pm 33.02$ & $122.39^{\mathrm{B}, \mathrm{ab}} \pm 45.39$ \\
\hline & 5 & $140.52^{\mathrm{A}, \mathrm{ab}} \pm 56.90$ & $115.59^{\mathrm{AB}} \pm 53.22$ & $83.32^{\mathrm{B}} \pm 28.42$ & $103.00^{\mathrm{AB}, \mathrm{ab}} \pm 34.36$ \\
\hline \multirow{5}{*}{$\beta$-phenylethylamine } & 1 & $5.00^{\mathrm{A}} \pm 2.37$ & $4.27^{\mathrm{AB}} \pm 1.77$ & $3.54^{\mathrm{AB}} \pm 0.54$ & $3.27^{\mathrm{B}} \pm 0.44$ \\
\hline & 2 & $5.15 \pm 3.10$ & $3.97 \pm 0.98$ & $4.17 \pm 0.98$ & $3.77 \pm 0.74$ \\
\hline & 3 & $9.81 \pm 11.80$ & $4.26 \pm 2.30$ & $3.93 \pm 1.54$ & $5.41 \pm 3.99$ \\
\hline & 4 & $6.05^{\mathrm{A}} \pm 2.90$ & $4.15^{\mathrm{AB}} \pm 1.00$ & $3.66^{B} \pm 0.66$ & $4.21^{\mathrm{AB}} \pm 1.78$ \\
\hline & 5 & $7.15^{\mathrm{A}} \pm 4.51$ & $3.95^{\mathrm{B}} \pm 1.11$ & $3.20^{B} \pm 0.58$ & $4.05^{\mathrm{B}} \pm 2.05$ \\
\hline \multirow{5}{*}{ putrescine } & 1 & $7.79^{C} \pm 2.75$ & $8.61^{\mathrm{BC}} \pm 2.29$ & $33.38^{B} \pm 25.68$ & $64.83^{\mathrm{A}, \mathrm{a}} \pm 38.26$ \\
\hline & 2 & $10.78^{\mathrm{B}} \pm 4.23$ & $10.63^{\mathrm{B}} \pm 10.72$ & $34.79^{\mathrm{A}} \pm 26.31$ & $31.00 \mathrm{AB}, \mathrm{b} \pm 26.31$ \\
\hline & 3 & $10.96^{\mathrm{B}} \pm 3.31$ & $9.84^{\mathrm{B}} \pm 3.79$ & $29.38^{\mathrm{A}} \pm 21.33$ & $15.94^{\mathrm{B}, \mathrm{b}} \pm 9.49$ \\
\hline & 4 & $11.52 \pm 4.18$ & $10.37 \pm 3.39$ & $21.35 \pm 12.40$ & $21.73^{b} \pm 17.16$ \\
\hline & 5 & $10.94 \pm 5.41$ & $9.81 \pm 3.72$ & $20.91 \pm 16.21$ & $19.58^{b} \pm 13.08$ \\
\hline \multirow{5}{*}{ cadaverine } & 1 & $18.90^{\mathrm{B}} \pm 5.38$ & $20.53^{\mathrm{B}} \pm 2.82$ & $1.88^{B} \pm 5.28$ & $27.58^{\mathrm{A}} \pm 9.67$ \\
\hline & 2 & $16.98^{\mathrm{B}} \pm 4.94$ & $22.80^{\mathrm{AB}} \pm 9.66$ & $21.16^{\mathrm{AB}} \pm 10.63$ & $30.75^{\mathrm{A}} \pm 14.49$ \\
\hline & 3 & $19.95 \pm 4.35$ & $23.62 \pm 14.76$ & $19.72 \pm 3.47$ & $21.86 \pm 10.60$ \\
\hline & 4 & $22.04 \pm 11.48$ & $19.32 \pm 4.07$ & $17.00 \pm 5.10$ & $22.48 \pm 8.94$ \\
\hline & 5 & $28.53 \pm 21.58$ & $18.65 \pm 4.14$ & $17.73 \pm 4.14$ & $18.83 \pm 8.28$ \\
\hline \multirow{5}{*}{ histamine } & 1 & $0.32 \pm 1.01$ & ND & $0.28^{a} \pm 0.54$ & $0.80 \pm 2.17$ \\
\hline & 2 & $0.55 \pm 0.92$ & ND & $\mathrm{ND}^{\mathrm{b}}$ & ND \\
\hline & 3 & $0.31 \pm 0.76$ & ND & $\mathrm{ND}^{\mathrm{b}}$ & ND \\
\hline & 4 & ND & ND & $\mathrm{ND}^{\mathrm{b}}$ & ND \\
\hline & 5 & ND & ND & $\mathrm{ND}^{\mathrm{b}}$ & ND \\
\hline \multirow{5}{*}{ tyramine } & 1 & $1.33^{C} \pm 0.85$ & $3.18^{C} \pm 1.90$ & $6.90^{\mathrm{B}} \pm 4.16$ & $10.46^{\mathrm{A}} \pm 2.37$ \\
\hline & 2 & $2.46^{\mathrm{B}} \pm 3.30$ & $4.86^{\mathrm{B}} \pm 2.14$ & $7.71^{\mathrm{A}} \pm 1.30$ & $8.79^{\mathrm{A}} \pm 2.62$ \\
\hline & 3 & $1.77^{\mathrm{C}} \pm 0.84$ & $3.91^{\mathrm{BC}} \pm 2.46$ & $7.50^{B} \pm 3.29$ & $13.17^{\mathrm{A}} \pm 5.59$ \\
\hline & 4 & $3.05^{\mathrm{B}} \pm 3.84$ & $4.62^{B} \pm 2.15$ & $7.25^{\mathrm{AB}} \pm 3.36$ & $12.41^{\mathrm{A}} \pm 7.68$ \\
\hline & 5 & $1.16^{C} \pm 1.01$ & $4.33^{\mathrm{B}} \pm 1.57$ & $6.69^{B} \pm 2.71$ & $10.63^{\mathrm{A}} \pm 3.09$ \\
\hline \multirow{5}{*}{ spermidine } & 1 & $17.19^{a} \pm 3.98$ & $17.70 \pm 4.09$ & $17.54 \pm 3.98$ & $20.60^{a} \pm 5.06$ \\
\hline & 2 & $16.03^{\mathrm{ab}} \pm 3.22$ & $22.83 \pm 16.45$ & $16.95 \pm 5.22$ & $16.30^{\mathrm{ab}} \pm 3.91$ \\
\hline & 3 & $16.84^{\mathrm{ab}} \pm 3.10$ & $12.69 \pm 4.16$ & $17.26 \pm 3.11$ & $18.75^{\mathrm{ab}} \pm 5.39$ \\
\hline & 4 & $13.76^{\mathrm{ab}} \pm 3.17$ & $15.54 \pm 2.40$ & $17.20 \pm 3.67$ & $13.99^{b} \pm 4.29$ \\
\hline & 5 & $11.74^{\mathrm{b}} \pm 5.73$ & $14.99 \pm 3.49$ & $16.66 \pm 4.81$ & $13.86^{\mathrm{b}} \pm 2.91$ \\
\hline \multirow{5}{*}{ spermine } & 1 & $100.50 \pm 63.95$ & $123.09 \pm 53.48$ & $121.76^{\mathrm{b}} \pm 43.20$ & $131.66 \pm 97.55$ \\
\hline & 2 & $101.61^{\mathrm{BC}} \pm 59.05$ & $155.32^{\mathrm{A}} \pm 46.65$ & $129.38^{\mathrm{AB}, \mathrm{ab}} \pm 32.05$ & $75.14^{C} \pm 12.01$ \\
\hline & 3 & $135.50^{\mathrm{AB}} \pm 51.05$ & $123.25^{\mathrm{BC}} \pm 53.32$ & $170.35^{\mathrm{A}, \mathrm{a}} \pm 33.24$ & $87.97^{C} \pm 17.18$ \\
\hline & 4 & $123.45 \pm 45.29$ & $139.22 \pm 33.36$ & $131.42^{\mathrm{ab}} \pm 52.51$ & $116.07 \pm 52.17$ \\
\hline & 5 & $125.90^{\mathrm{AB}} \pm 47.61$ & $154.76^{\mathrm{A}} \pm 46.47$ & $130.61^{\mathrm{AB}, \mathrm{ab}} \pm 29.46$ & $105.07^{B} \pm 31.85$ \\
\hline \multirow{5}{*}{ vasoactive amines } & 1 & $145.35^{\mathrm{ab}} \pm 107.45$ & $138.95 \pm 59.91$ & $84.89 \pm 45.05$ & $147.26 \pm 61.07$ \\
\hline & 2 & $120.32^{b} \pm 66.69$ & $128.71 \pm 51.95$ & $84.13 \pm 41.06$ & $116.90 \pm 22.14$ \\
\hline & 3 & $170.28^{\mathrm{A}, \mathrm{ab}} \pm 41.20$ & $141.22^{\mathrm{AB}} \pm 65.37$ & $104.52^{\mathrm{B}} \pm 32.42$ & $104.61^{\mathrm{B}} \pm 12.79$ \\
\hline & 4 & $217.31^{\mathrm{A}, \mathrm{a}} \pm 89.43$ & $116.00^{\mathrm{B}} \pm 37.38$ & $96.13^{B} \pm 32.53$ & $139.00^{\mathrm{B}} \pm 44.52$ \\
\hline & 5 & $148.82^{\mathrm{A}, \mathrm{ab}} \pm 58.82$ & $123.87^{\mathrm{AB}} \pm 53.42$ & $93.21^{\mathrm{B}} \pm 28.20$ & $117.68^{\mathrm{AB}} \pm 36.43$ \\
\hline \multirow{5}{*}{ total amines } & 1 & $289.73 \pm 164.49$ & $308.88 \pm 72.10$ & $275.45 \pm 70.97$ & $391.93^{a} \pm 184.28$ \\
\hline & 2 & $265.72 \pm 73.77$ & $340.29 \pm 73.77$ & $286.50 \pm 80.93$ & $270.08^{a b} \pm 39.99$ \\
\hline & 3 & $353.54^{\mathrm{A}} \pm 63.17$ & $310.62^{\mathrm{AB}} \pm 94.20$ & $341.23^{\mathrm{A}} \pm 68.58$ & $249.13^{B, b} \pm 29.69$ \\
\hline & 4 & $388.08^{\mathrm{A}} \pm 85.39$ & $300.46^{\mathrm{AB}} \pm 66.94$ & $283.10^{\mathrm{B}} \pm 68.44$ & $313.28^{\mathrm{AB}, \mathrm{ab}} \pm 112.86$ \\
\hline & 5 & $325.94 \pm 110.90$ & $322.09 \pm 104.02$ & $279.12 \pm 44.16$ & $275.03^{\mathrm{ab}} \pm 71.41$ \\
\hline
\end{tabular}

Data are expressed as means \pm SD. N.D.-not detected; detection limit for histamine is $0.20 \mathrm{mg} / \mathrm{kg}$. $1-\mathrm{control}$; 2-S. equorum S2M7/L. sakei CV3C2; 3-S. equorum S2M7/L. sakei CV3C2/yeast 2RB4; 4-S. xylosus CECT7057/L. sakei CECT7056; 5-S. xylosus CECT7057/L. sakei CECT7056/yeast 2RB4. For the same treatment and in the same row, distinct capital letters $\left({ }^{A-C}\right)$ represent significantly different means $(p<0.05)$. For each curing step and in the same column, distinct lowercase letters $\left({ }^{\mathrm{a}, \mathrm{b}}\right)$ represent significantly different means $(p<0.05)$. 
Table 3 shows that no differences were observed for histamine between curing steps and that the levels remained below $1.00 \mathrm{mg} / \mathrm{kg}$ for all treatments. Tyramine levels gradually increased throughout the curing process, with no significant differences between treatments. The mean values in end-products did not exceed $13.17 \pm 5.59 \mathrm{mg} / \mathrm{kg}$.

Regarding food safety, histamine and tyramine are the most toxic amines [65]. Daily maximum intakes of $50 \mathrm{mg}$ of histamine and $600 \mathrm{mg}$ of tyramine have been considered safe for healthy individuals [66]. However, Rauscher-Gabernig et al. [67] reported that the no-effect levels for alimentary histamine ranged from 6 to $25 \mathrm{mg} / \mathrm{meal}$, whereas the ingestion of $70 \mathrm{mg} / \mathrm{meal}$ could trigger intoxication symptoms and $100 \mathrm{mg} / \mathrm{meal}$, severe intoxications. Both tyramine and histamine had very low concentrations in the present work compared to those obtained by other authors $[18,68,69]$.

The presence of natural polyamines, spermidine and spermine followed the pattern usually found in dry-cured sausages, with the greater prevalence of the last over the first [70-74]. Furthermore, Kalač and Krausová [75] report that meat and meat products generally have concentrations that rarely exceed $10 \mathrm{mg} / \mathrm{kg}$ for spermidine and that levels between 20 and $60 \mathrm{mg} / \mathrm{kg}$ are already considered high for spermine. However, Tasić et al. [73] have determined values of $101 \mathrm{mg} / \mathrm{kg}$ for spermine in non-inoculated Serbian sausages. Kalač [76] states that the presence of higher amounts of spermine is common in foods of animal origin, although the relative proportion between these two biogenic amines may vary depending on the type of raw materials used in formulating the sausages, which is corroborated by Stadnik and Dolatowski [77] and Ruiz-Capillas and Jiménez-Colmenero [78], who say that the levels of natural polyamines are generally reduced or maintained throughout the curing process. Nevertheless, Hernández-Jover et al. [79] reported that a reduction in spermine levels is more common, because it can be used by some microorganisms as a source of nitrogen.

For vasoactive amines (tryptamine, $\beta$-phenylethylamine, histamine and tyramine), the levels were somewhat lower in half-cured sausages, compared with at the previous curing steps. However, they slightly increased in end-products, even if with no significant differences. Control sausages had the highest mean value $(147.26 \pm 61.07 \mathrm{mg} / \mathrm{kg})$, while sausages inoculated with S. equorum S2M7/L. sakei CV3C2/yeast 2RB4 had the lowest mean values, representing $28.96 \%$ less vasoactive amines. This corroborates the previous starter selection [22], showing that S. equorum S2M7 and L. sakei CV3C2 were low producers of biogenic amines. The addition of the yeast 2RB4 in co-culture with these two strains seems to reduce even further the production of biogenic amines, probably due to a better control of other bacterial strains able to produce biogenic amines.

Concerning the total content of biogenic amines, no significant differences were observed over time. However, control end-products showed the highest mean value $(391.93 \pm 184.28 \mathrm{mg} / \mathrm{kg})$, which was significantly different from the mean value of sausages inoculated with S. equorum S2M7/L. sakei CV3C2/yeast 2RB4 $(249.13 \pm 29.69 \mathrm{mg} / \mathrm{kg})$, representing a $36.44 \%$ reduction in total amines.

Regarding end-products, vasoactive amines were less than $200 \mathrm{mg} / \mathrm{kg}$ and total biogenic amines remained below $1000 \mathrm{mg} / \mathrm{kg}$. These are positive results in terms of hygiene, since Tasić et al. [73] cite several authors and point to values above $1000 \mathrm{mg} / \mathrm{kg}$ as hazardous to consumers' health. They also show, for some biogenic amines, the levels that are in compliance with good hygiene and manufacturing practices: 100 to $800 \mathrm{mg} / \mathrm{kg}$ for tyramine, 50 to $100 \mathrm{mg} / \mathrm{kg}$ for histamine, $<30 \mathrm{mg} / \mathrm{kg}$ for $\beta$-phenylethylamine, and values below $200 \mathrm{mg} / \mathrm{kg}$ for the sum of vasoactive amines. Vidal-Carou et al. [80] stress the importance of a careful raw material selection and production process to avoid or reduce the formation of biogenic amines. Silla Santos [81] indicate $\mathrm{pH}$ values between 4.0 and 5.5 as optimal for decarboxylation to occur. Others have reported the production of putrescine and cadaverine to be particularly associated with Gram-negative bacteria, mainly enterobacteria and pseudomonas $[66,82,83]$. In the present study, the $\mathrm{pH}$ mean value for the control end-products was significantly higher that for the inoculated sausages. Furthermore, the control sausages were the only ones to have enterobacteria $(0.86 \pm 1.33 \mathrm{log} \mathrm{cfu} / \mathrm{g})$ in end-products, which might be associated with their higher total amine content. 


\subsection{Colour}

Table 4 shows no significant differences between treatments for any of the colour parameters studied. However, the sausages inoculated with S. equorum S2M7/L. sakei CV3C2, S. equorum S2M7/L. sakei CV3C2/yeast 2RB4 and S. xylosus CECT7057/L. sakei CECT7056 were slightly darker and redder $\left(a^{*}\right)$ than the others. Considering the values obtained for the $C^{*}$ coordinate, the inoculated sausages were slightly redder and with a stronger and brighter (more defined) colour.

Table 4. Effect of starter cultures on the colour parameters of smoked fermented sausages evaluated in end-products.

\begin{tabular}{cccccc}
\hline \multirow{2}{*}{ Treatment } & \multicolumn{4}{c}{ Colour Parameters } \\
\cline { 2 - 5 } & $\mathbf{L}^{*}$ (Lightness) & $\mathbf{a}^{*}$ (Redness/Greenness) & $\mathbf{b}^{*}$ (Yellowness/Blueness) & $\mathbf{C}^{*}$ (Chroma) & $\mathbf{H}^{\circ}$ (Hue Angle) \\
\hline 1 & $48.40 \pm 5.52$ & $14.96 \pm 3.07$ & $11.91 \pm 3.44$ & $19.23 \pm 4.15$ & $38.26 \pm 6.01$ \\
2 & $46.70 \pm 6.76$ & $15.75 \pm 3.11$ & $12.50 \pm 3.37$ & $20.24 \pm 3.94$ & $38.23 \pm 6.78$ \\
3 & $47.80 \pm 5.59$ & $15.08 \pm 2.79$ & $13.13 \pm 3.30$ & $20.15 \pm 3.55$ & $40.81 \pm 6.95$ \\
4 & $46.98 \pm 5.90$ & $15.81 \pm 2.57$ & $12.75 \pm 4.02$ & $20.47 \pm 4.03$ & $38.13 \pm 7.14$ \\
5 & $49.30 \pm 5.83$ & $14.70 \pm 2.32$ & $12.62 \pm 3.26$ & $19.58 \pm 2.71$ & $40.29 \pm 8.71$ \\
\hline
\end{tabular}

Our results agree with those previously obtained by Essid and Hassouna [8], Casquete et al. [84] and Casaburi et al. [85], showing that starter cultures do not have a significant influence on colour parameters. Contrarily to our results, Lorenzo et al. [40] found that the use of starter cultures positively influenced the colour coordinates of sausages, while Casquete et al. [84] only identified an effect on the $\mathrm{H}^{\circ}$ coordinate.

\subsection{Texture Profile Analysis (TPA)}

The results for the Texture Profile Analysis (TPA) are shown in Table 5. Significant differences between treatments were observed only for adhesiveness, which was significantly higher in sausages inoculated with $S$. equorum S2M7/L. sakei CV3C2 $\left(-0.805 \pm 0.632 \mathrm{~N} \cdot \mathrm{s}^{-1}\right)$ and S. equorum S2M7/L. sakei CV3C2/yeast 2RB4, when compared to the non-inoculated sausages $\left(-0.302 \pm 0.293 \mathrm{~N} \cdot \mathrm{s}^{-1}\right)$. Furthermore, the inoculated sausages were harder and showed higher chewiness values.

Table 5. Effect of starter cultures on textural parameters of smoked fermented sausages evaluated in end-products.

\begin{tabular}{|c|c|c|c|c|c|c|}
\hline \multirow{2}{*}{ Treatment -} & \multicolumn{5}{|c|}{ Texture Parameters } & \multirow[b]{2}{*}{ Chewiness (N) } \\
\hline & Hardness (N) & Adhesiveness (N.s $\mathbf{s}^{-1}$ ) & Cohesiveness & Springiness & Resilience & \\
\hline 1 & $40.853 \pm 17.730$ & $-0.302^{b} \pm 0.293$ & $0.636 \pm 0.055$ & $0.855 \pm 0.071$ & $0.185 \pm 0.033$ & $22.665 \pm 10.459$ \\
\hline 2 & $53.168 \pm 18.532$ & $-0.805^{\mathrm{a}} \pm 0.632$ & $0.631 \pm 0.053$ & $0.853 \pm 0.061$ & $0.164 \pm 0.030$ & $28.754 \pm 9.840$ \\
\hline 3 & $50.918 \pm 18.852$ & $-0.775^{\mathrm{a}} \pm 0.831$ & $0.626 \pm 0.041$ & $0.864 \pm 0.075$ & $0.172 \pm 0.028$ & $27.892 \pm 11.051$ \\
\hline 4 & $48.518 \pm 14.997$ & $-0.425^{\mathrm{ab}} \pm 0.232$ & $0.627 \pm 0.040$ & $0.873 \pm 0.060$ & $0.177 \pm 0.026$ & $26.9892 \pm 10.28$ \\
\hline 5 & $47.067 \pm 21.018$ & $-0.639^{\mathrm{ab}} \pm 0.691$ & $0.629 \pm 0.052$ & $0.861 \pm 0.069$ & $0.181 \pm 0.033$ & $25.826 \pm 11.744$ \\
\hline
\end{tabular}

González-Fernández et al. [86] reported that $\mathrm{pH}$ values that reach the isoelectric point of proteins confer hardness and increase chewiness values due to the precipitation of proteins from sausages, a premise that the present work seems to corroborate.

Authors such as Lorenzo et al. [40] and Essid and Hassouna [8] concluded that inoculation with starter cultures did not have a significant effect on the textural characteristics of sausages, which were mainly influenced by ripening times. However, no comparison is possible with our results because we only carried out the determination of textural parameters in end-products. 
Nevertheless, Casquete et al. [84] inoculated P. acidilactici MS198 and S. vitulus RS34 at a concentration of approximately $5 \times 10^{7}$ cells/g meat batter, with $2.5 \%$ of added sucrose, and observed a reduction in the hardness of the Spanish sausages, probably due to the proteolysis promoted by these lactic acid bacterial starters.

\subsection{Sensory Analysis}

Concerning sensory analysis (Table 6), the panellists did not detect significant differences for any of the evaluated attributes. Nevertheless, the panellists preferred control sausages in terms of colour intensity and aroma.

The sausages co-inoculated with the yeast strain 2RB4 were the only ones that did not show off-colours.

Regarding instrumental texture (Table 5), control sausages were less hard than inoculated sausages. However, the sensory panel considered control sausages slightly harder than inoculated sausages, although without significant differences. This may be due to some heterogeneity between the samples used for the two sets of analyses and might be related to common differences among samples (e.g., sausage diameter or poor fat distribution in the evaluated sausage slices) or a biased panellists' assessment.

Concerning overall assessment, the sensory panel preferred the sausages inoculated with $S$. equorum S2M7/L. sakei CV3C2. 
Table 6. Effect of starter cultures on the sensory attributes of smoked fermented sausages evaluated in end-products.

\begin{tabular}{|c|c|c|c|c|c|c|c|c|c|c|c|c|}
\hline \multirow[b]{2}{*}{ Treatment } & \multicolumn{12}{|c|}{ Sensory Attributes } \\
\hline & $\begin{array}{c}\text { Colour } \\
\text { Intensity }\end{array}$ & $\begin{array}{c}\text { Off } \\
\text { Colours }\end{array}$ & Marbled & $\begin{array}{c}\text { Aroma } \\
\text { Intensity }\end{array}$ & $\begin{array}{c}\text { Off } \\
\text { Aromas }\end{array}$ & Hardness & Fibrousness & Succulence & $\begin{array}{c}\text { Flavour } \\
\text { Intensity }\end{array}$ & $\begin{array}{c}\text { Off } \\
\text { Flavours }\end{array}$ & $\begin{array}{c}\text { Salt } \\
\text { Perception }\end{array}$ & $\begin{array}{c}\text { Overall } \\
\text { Appreciation }\end{array}$ \\
\hline 1 & $66 \pm 9$ & $0 \pm 1$ & $56 \pm 1$ & $70 \pm 17$ & $1 \pm 5$ & $58 \pm 10$ & $39 \pm 27$ & $61 \pm 16$ & $69 \pm 11$ & $3 \pm 9$ & $60 \pm 8$ & $62 \pm 12$ \\
\hline 2 & $61 \pm 11$ & $0 \pm 1$ & $51 \pm 8$ & $65 \pm 10$ & $1 \pm 5$ & $56 \pm 10$ & $37 \pm 23$ & $58 \pm 18$ & $69 \pm 10$ & $4 \pm 1$ & $57 \pm 7$ & $64 \pm 10$ \\
\hline 3 & $63 \pm 12$ & $0 \pm 0$ & $50 \pm 5$ & $63 \pm 12$ & $2 \pm 5$ & $57 \pm 10$ & $38 \pm 27$ & $56 \pm 18$ & $68 \pm 11$ & $4 \pm 7$ & $61 \pm 7$ & $58 \pm 16$ \\
\hline 4 & $60 \pm 8$ & $1 \pm 3$ & $53 \pm 3$ & $64 \pm 11$ & $2 \pm 5$ & $53 \pm 10$ & $40 \pm 22$ & $60 \pm 18$ & $64 \pm 17$ & $4 \pm 7$ & $59 \pm 9$ & $61 \pm 15$ \\
\hline 5 & $61 \pm 12$ & $0 \pm 0$ & $55 \pm 8$ & $67 \pm 10$ & $2 \pm 5$ & $54 \pm 10$ & $38 \pm 24$ & $62 \pm 15$ & $70 \pm 8$ & $4 \pm 7$ & $58 \pm 9$ & $61 \pm 16$ \\
\hline
\end{tabular}

Data are expressed as means \pm SD. 1—control; 2—S. equorum S2M7/L. sakei CV3C2; 3—S. equorum S2M7/L. sakei CV3C2/yeast 2RB4; 4-S. xylosus CECT7057/L. sakei CECT7056; 5-S. xylosus CECT7057/L. sakei CECT7056/yeast 2RB4. In the same column, different letters represent significantly different means $(p<0.05)$. 


\section{Conclusions}

In the present study, the effect of autochthonous starter cultures on the safety and quality of a traditional Portuguese smoked fermented sausage, Painho da Beira Baixa, was evaluated. To our knowledge, this is the first comprehensive study on the quality and safety of this type of smoked fermented sausage from the central region of Portugal.

Starters did not have a noticeable effect on the reduction of $\mathrm{a}_{\mathrm{W}}$, nor did they improve colour. However, significantly lower $\mathrm{pH}$ values were obtained for inoculated sausages. Furthermore, the effect of starters was observed in the absence of detectable enterobacteria and L. monocytogenes in all inoculated sausages. Moreover, sausages inoculated with S. equorum S2M7/L. sakei CV3C2/yeast 2RB4 promoted a reduction of $28.96 \%$ and $36.44 \%$, respectively, for vasoactive and total amines. Nevertheless, regarding sensory evaluation, sausages inoculated with S. equorum S2M7/L. sakei CV3C2 had slightly higher scores in their sensory attributes. However, no influence on sensory attributes was observed in the co-inoculation with the yeast 2RB4, which was expected. This could probably be due to its lower ability to compete both with the autochthonous microbiota, as well as with the used bacterial starters.

In summary, the use of starter cultures did not compromise the quality of Painho da Beira Baixa regarding its sensory acceptability. Furthermore, some starters contributed to the safety of smoked fermented sausages, showing positive effects in reducing both the undesirable microbiota as well as the content of biogenic amines.

Author Contributions: Conceptualization, I.D., M.L. and M.E; methodology, M.L., M.E.P., A.C.A.-S., M.J.F.; formal analysis, I.D., S.R.-R., A.R.F. and J.V.; investigation, M.L., M.E.P., A.C.A.-S., M.J.F. and M.O.; writing-original draft preparation, I.D. and M.L.; writing-review and editing, I.D., M.L. and M.E.; supervision, M.L. and M.E.; funding acquisition, M.E. and M.J.F. All authors have read and agreed to the current version of the manuscript.

Funding: This work was supported by projects PDR2020-1.0.1-FEADER-031373 and PDR2020-1.0.1-FEADER031359, funded by national funds through Fundação para a Ciência e a Tecnologia (FCT)/MCTES and co-funded through the European Regional Development Fund (ERDF), and by projects UIDB/05183/2020 (MED) and UIDP/00276/2020 (CIISA) financed by national funds through FCT.

Acknowledgments: The authors thank O FUMEIRO DA BEIRA for their collaboration, and Antónia Oliveira and Guilhermina Pias for their technical assistance. Maria João Fraqueza is a member of the Red CYTED HEALTHY MEAT (119RT0568) network.

Conflicts of Interest: The authors declare no conflict of interests. The funders had no role in the design of the study; in the collection, analyses, or interpretation of data; in the writing of the manuscript, or in the decision to publish the results.

\section{References}

1. Franciosa, I.; Alessandria, V.; Dolci, P.; Rantsiou, K.; Cocolin, L. Sausage fermentation and starter cultures in the era of molecular biology methods. Int. J. Food Microbiol. 2018, 279, 26-32. [CrossRef] [PubMed]

2. Laranjo, M.; Elias, M.; Fraqueza, M.J. The Use of Starter Cultures in Traditional Meat Products. J. Food Qual. 2017, 2017, 1-18. [CrossRef]

3. Van Ba, H.; Seo, H.W.; Kim, J.H.; Cho, S.H.; Kim, Y.S.; Ham, J.S.; Park, B.Y.; Kim, H.W.; Kim, T.B.; Seong, P.N. The effects of starter culture types on the technological quality, lipid oxidation and biogenic amines in fermented sausages. Lwt-Food Sci. Technol. 2016, 74, 191-198. [CrossRef]

4. Kumar, P.; Chatli, M.K.; Verma, A.K.; Mehta, N.; Malav, O.P.; Kumar, D.; Sharma, N. Quality, functionality, and shelf life of fermented meat and meat products: A review. Crit. Rev. Food Sci. Nutr. 2017, 57, $2844-2856$. [CrossRef]

5. Laranjo, M.; Potes, M.E.; Elias, M. Role of Starter Cultures on the Safety of Fermented Meat Products. Front. Microbiol. 2019, 10, 853. [CrossRef]

6. Aro, J.M.A.; Nyam-Osor, P.; Tsuji, K.; Shimada, K.-I.; Fukushima, M.; Sekikawa, M. The effect of starter cultures on proteolytic changes and amino acid content in fermented sausages. Food Chem. 2010, 119, $279-285$. [CrossRef] 
7. Babić, I.; Markov, K.; Kovačević, D.; Trontel, A.; Slavica, A.; Dugum, J.; Čvek, D.; Svetec, I.K.; Posavec, S.; Frece, J. Identification and characterization of potential autochthonous starter cultures from a Croatian "brand" product "Slavonski kulen". Meat Sci. 2011, 88, 517-524. [CrossRef]

8. Essid, I.; Hassouna, M. Effect of inoculation of selected Staphylococcus xylosus and Lactobacillus plantarum strains on biochemical, microbiological and textural characteristics of a Tunisian dry fermented sausage. Food Control 2013, 32, 707-714. [CrossRef]

9. Latorre-Moratalla, M.L.; Bover-Cid, S.; Bosch-Fuste, J.; Vidal-Carou, M.C. Influence of technological conditions of sausage fermentation on the aminogenic activity of L. curvatus CTC273. Food Microbiol. 2012, 29, 43-48. [CrossRef]

10. Lu, S.; Ji, H.; Wang, Q.; Li, B.; Li, K.; Xu, C.; Jiang, C. The effects of starter cultures and plant extracts on the biogenic amine accumulation in traditional Chinese smoked horsemeat sausages. Food Control 2015, 50, 869-875. [CrossRef]

11. Lorenzo, J.M.; Munekata, P.E.S.; Domínguez, R. Role of autochthonous starter cultures in the reduction of biogenic amines in traditional meat products. Curr. Opin. Food Sci. 2017, 14, 61-65. [CrossRef]

12. Cruxen, C.E.d.S.; Braun, C.L.K.; Fagundes, M.B.; Gularte, M.A.; Wagner, R.; Padilha da Silva, W.; Fiorentini, Â.M. Development of fermented sausage produced with mutton and native starter cultures. Lwt-Food Sci. Technol. 2018, 95, 23-31. [CrossRef]

13. Cocconcelli, P.S.; Fontana, C. Bacteria. In Handbook of Fermented Meat and Poultry, 2nd ed.; Toldrá, F., Ed.; John Wiley \& Sons, Ltd.: Chichester, West Sussex, UK, 2015; pp. 117-128.

14. Montanari, C.; Gatto, V.; Torriani, S.; Barbieri, F.; Bargossi, E.; Lanciotti, R.; Grazia, L.; Magnani, R.; Tabanelli, G.; Gardini, F. Effects of the diameter on physico-chemical, microbiological and volatile profile in dry fermented sausages produced with two different starter cultures. Food Biosci. 2018, 22, 9-18. [CrossRef]

15. Selgas, M.D.; García, M.L. Yeasts. In Handbook of Fermented Meat and Poultry, 2nd ed.; Toldrá, F., Ed.; John Wiley \& Sons, Ltd.: Chichester, West Sussex, UK, 2015; pp. 139-146.

16. Corral, S.; Salvador, A.; Belloch, C.; Flores, M. Improvement the aroma of reduced fat and salt fermented sausages by Debaromyces hansenii inoculation. Food Control 2015, 47, 526-535. [CrossRef]

17. Berni, E. Molds. In Handbook of Fermented Meat and Poultry, 2nd ed.; Toldrá, F., Ed.; John Wiley \& Sons, Ltd.: Chichester, West Sussex, UK, 2015; pp. 147-154.

18. Simion, A.M.C.; Vizireanu, C.; Alexe, P.; Franco, I.; Carballo, J. Effect of the use of selected starter cultures on some quality, safety and sensorial properties of Dacia sausage, a traditional Romanian dry-sausage variety. Food Control 2014, 35, 123-131. [CrossRef]

19. Elias, M.; Potes, M.E.; Roseiro, L.C.; Santos, C.; Gomes, A.; Agulheiro-Santos, A.C. The Effect of Starter Cultures on the Portuguese Traditional Sausage "Paio do Alentejo" in Terms of Its Sensory and Textural Characteristics and Polycyclic Aromatic Hydrocarbons Profile. J. Food Res. 2014, 3, 45-56. [CrossRef]

20. Dias, I. Aplicação de Culturas Microbianas Autóctones na Produção de Enchidos Tradicionais do Alentejo e da Beira Baixa. Universidade de Évora, Évora. 2018. Available online: http://dspace.uevora.pt/rdpc/handle/ 10174/23437 (accessed on 27 April 2020).

21. Elias, M. Caracterização, conservação e produção biotecnológica de paio de porco alentejano. Universidade de Évora, Évora. 2004. Available online: http://dspace.uevora.pt/rdpc/handle/10174/11246 (accessed on 27 April 2020).

22. Alfaia, C.M.; Gouveia, I.M.; Fernandes, M.H.; Fernandes, M.J.; Semedo-Lemsaddek, T.; Barreto, A.S.; Fraqueza, M.J. Assessment of Coagulase-Negative Staphylococci and Lactic Acid Bacteria Isolated from Portuguese Dry Fermented Sausages as Potential Starters Based on Their Biogenic Amine Profile. J. Food Sci. 2018, 83, 2544-2549. [CrossRef]

23. ISO. Meat and Meat products - Measurement of $p H$ - Reference Method; International Organization for Standardization: Geneva, Switzerland, 1999; Volume 2917.

24. Fraqueza, M.J.; Laranjo, M.; Alves, S.; Fernandes, M.H.; Cristina, A.; Santos, A.; Fernandes, M.J.; Potes, M.E.; Elias, M. Dry - Cured Meat Products According to the Smoking Regime: Process Optimization to Control Polycyclic Aromatic Hydrocarbons. Foods 2020, 9, 91. [CrossRef]

25. Laranjo, M.; Agulheiro-Santos, A.C.; Potes, M.E.; Cabrita, M.J.; Garcia, R.; Fraqueza, M.J.; Elias, M. Effects of genotype, salt content and calibre on quality of traditional dry-fermented sausages. Food Control 2015, 56, 119-127. [CrossRef] 
26. ISO. Microbiology of the Food Chain-Horizontal Method for the Enumeration of Microorganisms—Part 1: Colony Count at 30 Degrees C by the Pour Plate Technique; International Organization for Standardization: Geneva, Switzerland, 2013; Volume ISO 4833-1.

27. ISO. Microbiology of Food and Animal Feeding Stuffs-Horizontal Method for the Enumeration of Psychrotrophic Microorganisms; International Organization for Standardization: Geneva, Switzerland, 2001; Volume ISO 17410.

28. ISO. Microbiology of Food and Animal Feeding Stuffs-Horizontal Method for the Enumeration of Mesophilic Lactic Acid Bacteria-Colony-Count Technique at 30 Degrees C; International Organization for Standardization: Geneva, Switzerland, 2013; Volume ISO 15214.

29. Laranjo, M.; Gomes, A.; Agulheiro-Santos, A.C.; Potes, M.E.; Cabrita, M.J.; Garcia, R.; Rocha, J.M.; Roseiro, L.C.; Fernandes, M.J.; Fraqueza, M.J.; et al. Impact of salt reduction on biogenic amines, fatty acids, microbiota, texture and sensory profile in traditional blood dry-cured sausages. Food Chem. 2017, 218, 129-136. [CrossRef]

30. ISO. Microbiology of Food and Animal Feeding Stuffs-Horizontal Method for the Enumeration of Yeasts and Moulds-Part 2: Colony Count Technique in Products with Water Activity Less than or Equal to 0,95; International Organization for Standardization: Geneva, Switzerland, 2008; Volume ISO 21527-2.

31. ISO. Microbiology of the Food Chain-Horizontal Method for the Detection and Enumeration of Enterobacteriaceae-Part 2: Colony-Count Technique; International Organization for Standardization: Geneva, Switzerland, 2017; Volume ISO 21528-2.

32. ISO. Microbiology of the food chain - Horizontal method for the detection and enumeration of Listeria monocytogenes and of Listeria spp.-Part 2: Enumeration method; International Organization for Standardization: Geneva, Switzerland, 2014; Volume ISO 11290-2.

33. ISO. Microbiology of Food and Animal Feeding Stuffs-Horizontal Method for the Detection of Salmonella spp.; International Organization for Standardization: Geneva, Switzerland, 2002; Volume ISO 6579.

34. Roseiro, C.; Santos, C.; Sol, M.; Silva, L.; Fernandes, I. Prevalence of biogenic amines during ripening of a traditional dry fermented pork sausage and its relation to the amount of sodium chloride added. Meat Sci. 2006, 74, 557-563. [CrossRef] [PubMed]

35. Elias, M.; Fraqueza, M.J.; Laranjo, M. Biogenic Amines in Food: Presence and Control Measures. In Biogenic Amines (BA): Origins, Biological Importance and Human Health Implications; Stadnik, J., Ed.; Nova Science Publishers, Inc.: New York, NY, USA, 2018; pp. 129-176.

36. ISO. Sensory Analysis-General Guidelines for the Selection, Training and Monitoring of Selected Assessors and Expert Sensory Assessors; International Organization for Standardization: Geneva, Switzerland, 2012; Volume 8586.

37. ISO. Sensory Analysis-General Guidance for the Design of Test Rooms; International Organization for Standardization: Geneva, Switzerland, 2012; Volume ISO 8589.

38. McLeod, A.; Zagorec, M.; Champomier-Vergès, M.-C.; Naterstad, K.; Axelsson, L. Primary metabolism in Lactobacillus sakei food isolates by proteomic analysis. BMC Microbiol. 2010, 10, 120. [CrossRef] [PubMed]

39. Zhao, L.; Jin, Y.; Ma, C.; Song, H.; Li, H.; Wang, Z.; Xiao, S. Physico-chemical characteristics and free fatty acid composition of dry fermented mutton sausages as affected by the use of various combinations of starter cultures and spices. Meat Sci. 2011, 88, 761-766. [CrossRef] [PubMed]

40. Lorenzo, J.M.; Gómez, M.; Fonseca, S. Effect of commercial starter cultures on physicochemical characteristics, microbial counts and free fatty acid composition of dry-cured foal sausage. Food Control 2014, 46, 382-389. [CrossRef]

41. Leistner, L.; Rödel, W. The Significance of Water Activity for Micro-organisms in Meats. In Water Relations of Foods, Roudaut, R.B. Ed.; Academic Press: New York, NY, USA, 1975; pp. 309-323. [CrossRef]

42. Hierro, E.; Ordóñez, J.A.; Bruna, J.M.; Pin, C.; Fernández, M.; De La Hoz, L. Volatile compound generation in dry fermented sausages by the surface inoculation of selected mould species. Eur. Food Res. Technol. 2005, 220, 494-501. [CrossRef]

43. Bonardi, S.; Bruini, I.; Bolzoni, L.; Cozzolino, P.; Pierantoni, M.; Brindani, F.; Bellotti, P.; Renzi, M.; Pongolini, S. Assessment of Salmonella survival in dry-cured Italian salami. Int. J. Food Microbiol. 2017, 262, 99-106. [CrossRef]

44. Diez, J.G.; Patarata, L. Behavior of Salmonella spp., Listeria monocytogenes, and Staphylococcus aureus in Chouriço de Vinho, a dry fermented sausage made from wine-marinated meat. J. Food Prot. 2013, 76, 588-594. [CrossRef] 
45. Hajmeer, M.N.; Tajkarimi, M.; Gomez, E.L.; Lim, N.; O’Hara, M.; Riemann, H.P.; Cliver, D.O. Thermal death of bacterial pathogens in linguiça smoking. Food Control 2011, 22, 668-672. [CrossRef]

46. Lorenzo, J.M.; Franco, D. Fat effect on physico-chemical, microbial and textural changes through the manufactured of dry-cured foal sausage Lipolysis, proteolysis and sensory properties. Meat Sci. 2012, 92, 704-714. [CrossRef]

47. Lücke, F.K.; Vogeley, I. Traditional 'air-dried' fermented sausages from Central Germany. Food Microbiol. 2012, 29, 242-246. [CrossRef]

48. Spaziani, M.; Torre, M.D.; Stecchini, M.L. Changes of physicochemical, microbiological, and textural properties during ripening of Italian low-acid sausages. Proteolysis, sensory and volatile profiles. Meat Sci. 2009, 81, 77-85. [CrossRef] [PubMed]

49. Fraqueza, M.J. Antibiotic resistance of lactic acid bacteria isolated from dry-fermented sausages. Int. J. Food Microbiol. 2015, 212, 76-88. [CrossRef] [PubMed]

50. Fuka, M.M.; Tanuwidjaja, I.; Maksimovic, A.Z.; Zunabovic-Pichler, M.; Kublik, S.; Hulak, N.; Domig, K.J.; Schloter, M. Bacterial diversity of naturally fermented game meat sausages: Sources of new starter cultures. Lwt-Food Sci. Technol. 2020, 118, 108782. [CrossRef]

51. Benito, M.J.; Martín, A.; Aranda, E.; Pérez-Nevado, F.; Ruiz-Moyano, S.; Córdoba, M.G. Characterization and selection of autochthonous lactic acid bacteria isolated from traditional Iberian dry-fermented salchichón and chorizo sausages. J. Food Sci. 2007, 72. [CrossRef] [PubMed]

52. Elias, M.; Carrascosa, A.V. Characterisation of the Paio do Alentejo, a traditional Portuguese Iberian sausage, in respect to its safety. Food Control 2010, 21, 97-102. [CrossRef]

53. Casquete, R.; Benito, M.J.; Martín, A.; Ruiz-Moyano, S.; Aranda, E.; Córdoba, M.G. Microbiological quality of salchichón and chorizo, traditional Iberian dry-fermented sausages from two different industries, inoculated with autochthonous starter cultures. Food Control 2012, 24, 191-198. [CrossRef]

54. Fraqueza, M.J.; Patarata, L. Fermented meat products-from the technology to the quality control. In Fermented Food Products; Sankaranarayanan, A., Amaresan, N., Dhanasekaran, D., Eds.; CRC Press-Taylor \& Francis Group: Boca Raton, FL, USA, 2020; pp. 197-237.

55. Stavropoulou, D.A.; De Maere, H.; Berardo, A.; Janssens, B.; Filippou, P.; De Vuyst, L.; De Smet, S.; Leroy, F. Species pervasiveness within the group of coagulase-negative staphylococci associated with meat fermentation is modulated by pH. Front. Microbiol. 2018, 9, 1-11. [CrossRef]

56. Cadavez, V.; Gonzales-Barron, U.; Pires, P.; Fernandes, E.; Pereira, A.P.; Gomes, A.; Araújo, J.P.; Lopes-da-Silva, F.; Rodrigues, P.; Fernandes, C.; et al. An assessment of the processing and physicochemical factors contributing to the microbial contamination of salpicão, a naturally-fermented Portuguese sausage. Lwt - Food Sci. Technol. 2016, 72, 107-116. [CrossRef]

57. Garcia Fontan, M.C.; Lorenzo, J.M.; Parada, A.; Franco, I.; Carballo, J. Microbiological characteristics of “androlla", a Spanish traditional pork sausage. Food Microbiol. 2007, 24, 52-58. [CrossRef]

58. Andrade, M.a.J.; Córdoba, J.J.; Casado, E.M.a.; Córdoba, M.G.; Rodríguez, M. Effect of selected strains of Debaryomyces hansenii on the volatile compound production of dry fermented sausage "salchichón". Meat Sci. 2010, 85, 256-264. [CrossRef]

59. Encinas, J.-P.; López-Díaz, T.M.; García-López, M.L.; Otero, A.; Moreno, B. Yeast populations on Spanish fermented sausages. Meat Sci. 2000, 54, 203-208. [CrossRef]

60. Leistner, L. Stable and safe fermented sausages world-wide. In Fermented meats; Campbell-Platt, G., Cook, P.E., Eds.; Blackie Academic \& Professional: London, UK, 1995; pp. 160-175.

61. Alves, S.P.; Fernandes, M.J.; Fernandes, M.H.; Bessa, R.J.B.; Laranjo, M.; Ana, A.C.; Elias, M.; Fraqueza, M.J. Quality and Acceptability of Dry Fermented Sausages Prepared with Low Value Pork Raw Material. J. Food Process. Preserv. 2017, 41,1-10. [CrossRef]

62. Sunesen, L.O.; Stahnke, L.H. Mould starter cultures for dry sausages-selection, application and effects. Meat Sci. 2003, 65, 935-948. [CrossRef]

63. EC. Commission Regulation (EC) No. 1441/2007 of 5 December 2007 on microbiological criteria for foodstuffs. Off. J. Eur. Union 2007, L 322, 12-29.

64. Cenci-Goga, B.T.; Ranucci, D.; Miraglia, D.; Cioffi, A. Use of starter cultures of dairy origin in the production of Salame nostrano, an Italian dry-cured sausage. Meat Sci. 2008, 78, 381-390. [CrossRef] [PubMed] 
65. Del Rio, B.; Redruello, B.; Linares, D.M.; Ladero, V.; Fernandez, M.; Martin, M.C.; Ruas-Madiedo, P.; Alvarez, M.A. The dietary biogenic amines tyramine and histamine show synergistic toxicity towards intestinal cells in culture. Food Chem. 2017, 218, 249-255. [CrossRef] [PubMed]

66. EFSA. Scientific Opinion on risk based control of biogenic amine formation in fermented foods. Efsa J. 2011, 9, 1-93. [CrossRef]

67. Rauscher-Gabernig, E.; Gabernig, R.; Brueller, W.; Grossgut, R.; Bauer, F.; Paulsen, P. Dietary exposure assessment of putrescine and cadaverine and derivation of tolerable levels in selected foods consumed in Austria. Eur. Food Res. Technol. 2012, 235, 209-220. [CrossRef]

68. Bover-Cid, S.; Izquierdo-Pulido, M.; Carmen Vidal-Carou, M. Changes in biogenic amine and polyamine contents in slightly fermented sausages manufactured with and without sugar. Meat Sci. 2001, 57, 215-221. [CrossRef]

69. Latorre-Moratalla, M.L.; Comas-Basté, O.; Bover-Cid, S.; Vidal-Carou, M.C. Tyramine and histamine risk assessment related to consumption of dry fermented sausages by the Spanish population. Food Chem. Toxicol. 2017, 99, 78-85. [CrossRef]

70. Laranjo, M.; Gomes, A.; Agulheiro-Santos, A.C.; Potes, M.E.; Cabrita, M.J.; Garcia, R.; Rocha, J.M.; Roseiro, L.C.; Fernandes, M.J.; Fernandes, M.H.; et al. Characterisation of "Catalão" and "Salsichão" Portuguese traditional sausages with salt reduction. Meat Sci. 2016, 116, 34-42. [CrossRef]

71. Papavergou, E.J.; Savvaidis, I.N.; Ambrosiadis, I.A. Levels of biogenic amines in retail market fermented meat products. Food Chem. 2012, 135, 2750-2755. [CrossRef] [PubMed]

72. Roseiro, L.C.; Gomes, A.; Gonçalves, H.; Sol, M.; Cercas, R.; Santos, C. Effect of processing on proteolysis and biogenic amines formation in a Portuguese traditional dry-fermented ripened sausage "Chouriço Grosso de Estremoz e Borba PGI". Meat Sci. 2010, 84, 172-179. [CrossRef] [PubMed]

73. Tasić, T.; Ikonić, P.; Mandić, A.; Jokanović, M.; Tomović, V.; Savatić, S.; Petrović, L. Biogenic amines content in traditional dry fermented sausage Petrovská klobása as possible indicator of good manufacturing practice. Food Control 2012, 23, 107-112. [CrossRef]

74. Alves, S.P.; Alfaia, C.M.; Škrbić, B.D.; Živančev, J.R.; Fernandes, M.J.; Bessa, R.J.B.; Fraqueza, M.J. Screening chemical hazards of dry fermented sausages from distinct origins: Biogenic amines, polycyclic aromatic hydrocarbons and heavy elements. J. Food Compos. Anal. 2017, 59, 124-131. [CrossRef]

75. Kalač, P.; Krausová, P. A review of dietary polyamines: Formation, implications for growth and health and occurrence in foods. Food Chem. 2005, 90, 219-230. [CrossRef]

76. Kalač, P. Recent advances in the research on biological roles of dietary polyamines in man. J. Appl. Biomed. 2009, 7, 65-74. [CrossRef]

77. Stadnik, J.; Dolatowski, Z.J. Biogenic Amines in Meat and Fermented Meat Products. Acta Sci. Pol. Technol. Aliment. 2010, 9, 251-263.

78. Ruiz-Capillas, C.; Jiménez-Colmenero, F. Biogenic amines in meat and meat products. Crit. Rev. Food Sci. Nutr. 2004, 44, 489-499. [CrossRef]

79. Hernández-Jover, T.; Izquierdo-Pulido, M.; Veciana-Nogués, M.T.; Mariné-Font, A.; Vidal-Carou, M.C. Biogenic Amine and Polyamine Contents in Meat and Meat Products. J. Agric. Food Chem. 1997, 45, 2098-2102. [CrossRef]

80. Vidal-Carou, M.C.; Veciana-Nogués, M.T.; Latorre-Moratalla, M.L.; Bover-Cid, S. Biogenic Amines: Risks and Control. In Handbook of Fermented Meat and Poultry, 2nd ed.; Toldrá, F., Ed.; John Wiley \& Sons, Ltd.: Chichester, West Sussex, UK, 2015; pp. 413-428.

81. Silla Santos, M.H. Biogenic amines: Their importance in foods. Int. J. Food Microbiol. 1996, $29,213-231$. [CrossRef]

82. González-Tenorio, R.; Fonseca, B.; Caro, I.; Fernández-Diez, A.; Kuri, V.; Soto, S.; Mateo, J. Changes in biogenic amine levels during storage of mexican-style soft and spanish-style dry-ripened sausages with different aw values under modified atmosphere. Meat Sci. 2013, 94, 369-375. [CrossRef] [PubMed]

83. Sun, Q.; Chen, Q.; Li, F.; Zheng, D.; Kong, B. Biogenic amine inhibition and quality protection of Harbin dry sausages by inoculation with Staphylococcus xylosus and Lactobacillus plantarum. Food Control 2016, 68, 358-366. [CrossRef]

84. Casquete, R.; Benito, M.J.; Martín, A.; Ruiz-Moyano, S.; Córdoba, J.J.; Córdoba, M.G. Role of an autochthonous starter culture and the protease EPg222 on the sensory and safety properties of a traditional Iberian dry-fermented sausage "salchichón". Food Microbiol. 2011, 28, 1432-1440. [CrossRef] [PubMed] 
85. Casaburi, A.; Di Monaco, R.; Cavella, S.; Toldrá, F.; Ercolini, D.; Villani, F. Proteolytic and lipolytic starter cultures and their effect on traditional fermented sausages ripening and sensory traits. Food Microbiol. 2008, 25, 335-347. [CrossRef]

86. González-Fernández, C.; Santos, E.M.; Rovira, J.; Jaime, I. The effect of sugar concentration and starter culture on instrumental and sensory textural properties of chorizo-Spanish dry-cured sausage. Meat Sci. 2006, 74, 467-475. [CrossRef]

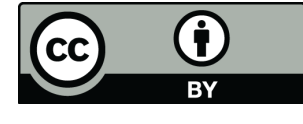

(C) 2020 by the authors. Licensee MDPI, Basel, Switzerland. This article is an open access article distributed under the terms and conditions of the Creative Commons Attribution (CC BY) license (http://creativecommons.org/licenses/by/4.0/). 